\title{
CIÊNCIA'NATURA
}

\section{Structural characteristics and biotechnological applications of frutalin, a lectin extracted from Artocarpus incisa}

\author{
Bianca Régia SilvaI, Franscisco Léo Nascimento de Aguiar ${ }^{I I}$ and José Roberto Viana Silva ${ }^{I I *}$

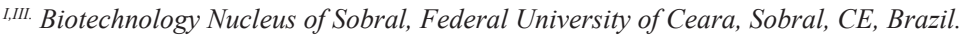 \\ II. Laboratory of Manipulation of Oocytes and Preantral Follicles (LAMOFOPA), State University of Ceará, Fortaleza, Ceará, Brazil
}

\begin{abstract}
Frutalin is a lectin extracted from the seeds of Artocarpus incisa, which belongs to the Moreacae family. This family consists of approximately 75 genera and 1,550 tropical species that are commonly found in pan-tropical regions. Frutalin has attracted the attention of researchers due to its ability to recognize carbohydrates in cell membranes with modifications in the glycosylation pattern. Therefore, frutalin presents a striking potential to be used as biomarker of cancer cells. Despite having a great biotechnological potential, research involving this lectin is still limited. Thus, the aim of this review is to discuss the structural and functional characteristics of frutalin, properties, the mechanisms of action, as well as the biotechnological applications of this lectin.
\end{abstract}

Keywords: Artocarpus incisa, frutalin, toxicity. 


\section{Introduction}

Lectins are glycoproteins of nonimmune origin, which have at least one non-catalytic domain that allows them to selectively recognize and bind to specific mono and oligosaccharides in a reversible manner (Peumans and Van dame 1995). These proteins have the particular ability to discriminate glycoconjugate complexes without promoting modifications in the molecular pattern (HirabayashI et al. 2011).

The lectins are found on a large scale in a variety of living organisms, such as in plants (Carvalho et al. 2015), vertebrates (Zhang 2016) and invertebrates (Bauters et al. 2017). In addition, to have different shapes and sizes, lectins play several important biological roles (Gallego Del Sol et al. 2005). Among the biological functions, it is possible to mention the participation in the process of cell-cell recognition during fertilization, defense and cellular organization, as well as in the transport of carbohydrates and its fixation in the tissues (Kan et al. 2008; Jiang et al. 2006; Silva et al. 2008; Yoon et al. 2008; Han et al. 2010).

Among the lectins, frutalin (FTL) is extracted from the seeds of Artocarpus incisa L. This lectin has a tetrameric form and $\alpha$-D-galactose specific link (Monteiro-Moreira et al. 2015). Then, due to its binding characteristics, FTL can recognize and fix to cell membranes, and even penetrate into the cell nucleus, influencing cell-cell interactions, communication, proliferation, and cell death mechanism (Sharon 2004; Oliveira et al. 2011). Accordingly, many biological activities have already been reported for this lectin, such as acute and neuropathic nociceptive effects (Damasceno et al. 2016), induction of neutrophil migration in vitro and in vivo, induction of chemotaxis, reorganization of the cytoskeleton of human neutrophils, cellular motility, and oxidative response (Roche et al. 2006). In addition, studies have shown that FTL can be used in the diagnosis of prostate, breast and thyroid cancer, as well as acute lymphoblastic leukemia (Oliveira et al. 2009). However, even with a prodigious biotechnological potential, little attention has been given to FTL. Thus, the objective of this review was to discuss the structural and the functional characteristics of FTL, its mechanisms of action, as well as its promising biotechnological applications.

\section{Characteristics and structural aspects of frutalin}

Artocarpus incisa is a medium-sized tree, up to 15 meters in height, with deep roots and a smooth gray bark stem with 80 to $90 \mathrm{~cm}$ in diameter. It has large leaves (30 to $90 \mathrm{~cm}$ long by 30 to $45 \mathrm{~cm}$ wide), varying in simple, coriaceous, curved at the base, cut in 5 to 7 wolves, rarely whole, and dark green color. Its flowers do not have petals and are very small (Moreira 1998).

Several lectins have already been isolated and characterized from Artocarpus incisa. As example, the frutapin, a specific mannose lectin that shares many similarities to the lectins extracted from Artocarpus intregrifolia (Monteiro 1997). Furthermore, FTL was extracted from the breadfruit, which is a glycoprotein alpha-D-galactose binding lectin containing $2.1 \%$ of carbohydrates in its structure. This lectin exhibits high levels of acid, hydroxylated and hydrophobic amino acids and low content of sulfuric amino acids (Monteiro 1998).

The FTL is a tetrameric protein, with a molecular mass of $48 \mathrm{KDa}$, and a tetramer conformation only at alkaline $\mathrm{pH}$ of 10, containing 153 aminoacids per monomer (Moreira 1998). Depending on the medium, the predominant three-dimensional shape is the antiparallel $\beta$-sheet (64\%) containing four $\alpha$-D-galactose binding sites, and it can be classified as hololectin. Its

Figure 1 - Crystallographic structure of the lectin frutalin. Each color represents the four monomers

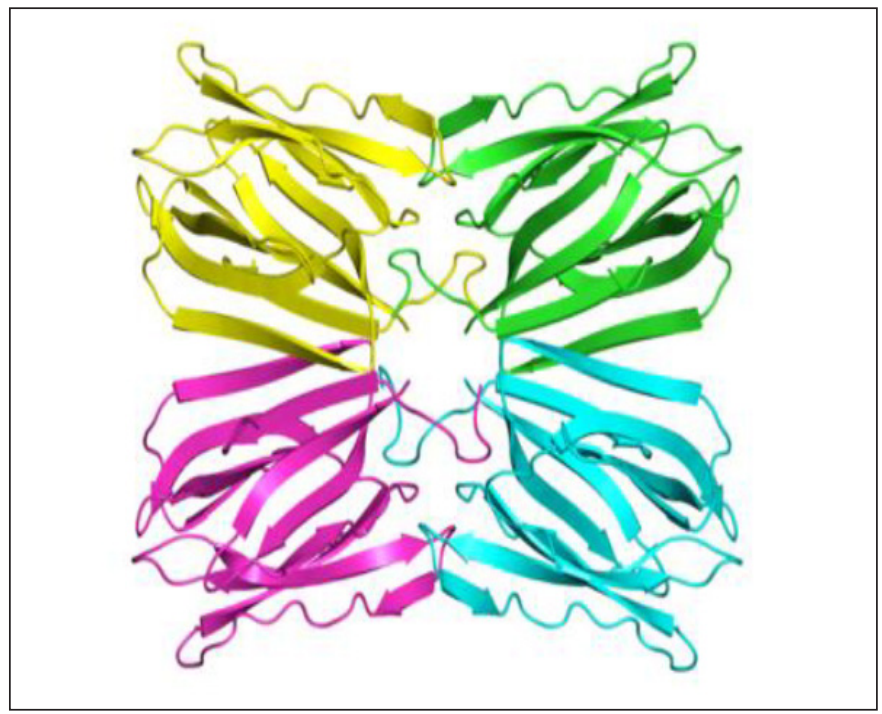


structure was described by Nepomuceno (2008) through homology modeling using the jacalin as a template protein. Previous studies demonstrated its three-dimensional structure through crystallization and analysis of data obtained by x-ray diffraction, showing that the FTL has in each monomeric unit a symmetric $\beta$ prism with three groups of four $\beta$-sheets each (Vieira-Neto 2015). The carbohydrate recognition site is similar to the observed for jacalin, and is involved in the N-terminal region of the $\alpha$ chain, presenting a characteristic folding of the family Moraceae. The FTL binding site consists of a cavity near the N-terminal of the $\alpha$ chain, formed by four key residues: Gly25, Tyr146, Trp147, and Asp149. Recent studies performed by Pereira et al. (2015) led to the determination of the crystallographic structure of the FTL, and showed that it is expressed in different isoforms, which presents variances mainly in post-transductional glycosylation (Figure 1).

The protein FTL is fairly stable and the thermal denaturation triggers almost simultaneously a loosening of the tertiary structure, loss of hemagglutinating activity, and organization of secondary structure. When treated at different pH values, FTL only shows significant modifications at the secondary and tertiary structure levels, and only at $\mathrm{pH} 12$. In addition, chaotropic agents are capable of denaturing FTL (Monteiro 1998).

\section{Main biological activities of frutalin}

\subsection{Frutalin as a biomarker of neoplastic cells}

Some aberrant changes in the plasma membrane glycosylation pattern are common in malignant cells, which can influence cell growth and differentiation. Previous studies showed the presence of endogenous lectins (galectins) only in precursor lesions and carcinomas (Schoeppner et al. 1995; Lalwani et al. 1996). On the other hand, with the use of vegetable lectins, such as FTL, it is possible to highlight changes in cellular glycoconjugates. Furthermore, during transformation and neoplastic progression, there is a specific reorganization of glycoproteins present on the cell surface, exposing $\alpha$-D-galactose residues to an interaction with FLT (Brockhausen 1999). Due to these changes in the glycosylation pattern in cell membranes, a particular fixation of FTL to $\alpha$-D-galactose has been tested with the purpose of identifying malignant cells (Figure 2). As aforementioned reported by Ferreira (2001), the efficiency of FTL to identify malignant lesions in the breast demonstrated an ability to mark the neoplastic tissues predominantly in the cell membranes. As a result, a low intensity of cytoplasm penetration has been observed, with the increase in tumor progression. Likewise, Milhome (2003) used FTL in the study of human thyroid cancer, and concluded that FTL is an excellent marker for malign and benign cell differentiation in thyroid lesions, acting like galectin 3- labeling, an endogenous lectin biomarker of cancer cells.

Previous studies using FTL for the detection of cells associated with Hodgking lymphoma were performed by Constâncio et al. (2005). It was observed that FTL can be used to detect Reed Sternberg (RS) cells, which are cells commonly associated with Hodgking lymphoma. The FTL was also used to identify malignant cells of the human prostate cancer by the immu-

Figure 2 - Representation of the interaction between lectin-carbohydrate on the cell surface

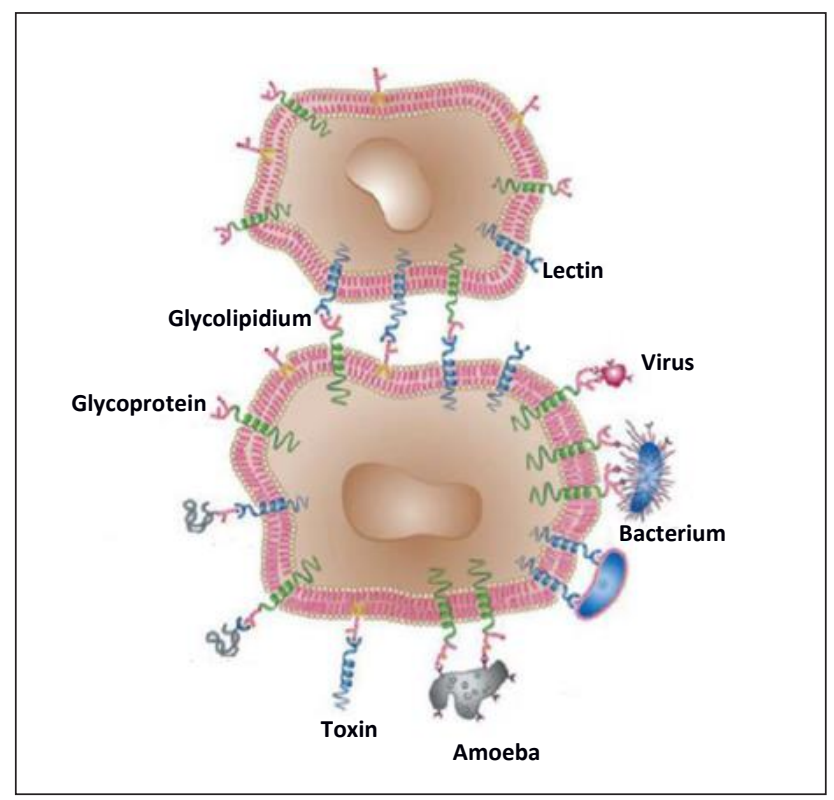


nohistochemistry technique. It was described that the native FTL was compared to the recombinant form, which is obtained by using the expression system of Pichia pastoris. As a consequence, after analysis of 20 cases of prostate carcinoma, and 25 cases of benign prostatic hyperplasia, the results showed that native and recombinant FTL have different binding responses in the prostatic tissues, due to their disparities in carbohydrate binding affinities. This is explained by the molecular modifications found between native and recombinant FTL. Therefore, it has been demonstrated that both lectins can be used as histochemical biomarkers for prostate cancer (Oliveira et al. 2009).

Recently, the potential of FTL for the premature diagnosis followed by treatment of acute B-cell lymphoblastic leukemia in vivo has been investigated (Cavalcante et al. 2016). It was conducted the proteomic analysis of serum from pediatric patients with acute B-cell lymphoblastic leukemia (B-ALL) to identify viable biomarkers for using in early diagnosis and treatment evaluation. From this study, a panel of possible biomarkers of proteins were developed for the pre-diagnosis of B-ALL and FTL demonstrated great potential for detection of this pathology. In addition to bind cancer cells, FTL can have numerous biotechnological applications in this area. As for example, the use as carbohydrate binding probes on the cell surfaces. In addition, it can be used as tumor-specific markers with the production of neoglycoproteins, neoglycoenzymes, pseudopolysaccharides, and anti-lectin antibodies, which may be associated with radioisotopes, enzymes, fluorochromes, biotin, anticancer drugs, cytotoxins and oligonucleotides.

\subsection{Mechanisms of frutalin action and biotechnological applications}

Frutalin specifically binds to homotetrameric $\alpha$-D-galactose (d-Gal), which activates natural killer cells in vitro and promotes leukocyte migration in vivo. Lectins are potent lymphocyte stimulators (Brando-Lima et al. 2006), and the understanding of the interactions that occur between the molecules in the cell surfaces may aid to elucidate the mechanisms of action involved in this process.

Brando-Lima (2006) verified how FTL is capable of inducing changes in the cytoskeleton and cellular motility. Then, the authors reported that the interaction of FTL with $\alpha$-D-galactose in lymphocyte membranes triggers the activation of the PI3K-Akt and NF$\mathrm{Nb}$ pathways, which modulates T-cell expression and proliferation, IL-2 synthesis, and expression of IL-2R. In addition, the authors demonstrated that FTL promotes cellular oxidation by increasing $\mathrm{H}_{2} \mathrm{O}_{2}$ production. Moreover, it is known that $\mathrm{H}_{2} \mathrm{O}_{2}$ causes significant mitochondrial damage, lipid peroxidation, and apoptosis in mouse granulosa cells (Tanabe 2015). In this context, Soares et al. (2018) reported the effects of FTL $(0.6,6.0$ or $60.0 \mu \mathrm{g} / \mathrm{mL})$ and doxorubicin $(0.3 \mu \mathrm{g} / \mathrm{mL})$ on the survival, growth, and ultrastructure of in vitro cultured goat secondary follicles. As main results, after 6 days of culture, FTL or doxorubicin reduced the percentage of normal follicles $(\mathrm{P}<0.05)$, nonetheless doxorubicin showed greater toxicity when compared to FTL. The deleterious effects of FTL were mainly on granulosa cells, whereas doxorubicin caused degeneration in granulosa and oocyte cells. Besides, a study conducted by the same group, demonstrated the effects of FTL $(1,10,50,100$, and $200 \mu \mathrm{g} / \mathrm{mL})$ on the morphology of primordial follicles, ultrastructure, and gene expression in goat ovarian tissue cultured in vitro. These authors showed that $50 \mu \mathrm{g} / \mathrm{mL}$ FTL negatively affects follicle and ultrastructurel and a large number of vacuoles were distributed throughout the oocyte cytoplasm, and signs of damage to mitochondrial membranes and ridges were also observed (Soares et al. 2018).

Oliveira et al. (2011) tested both native and recombinant FTL and showed that it can be completely internalized and activate apoptotic pathways in HeLa cells. In this study, the authors verified through imonolocalization technique, that native FTL can penetrate into the perinuclear space, where the fluorescence was most evidenced. However, the analysis of recombinant FTL had greater fluorescence found in the nucleus of HeLa cells. It is relevant to clarify that high FTL concentrations are correlated with more toxicity.

The effect of FTL on diseases of the central nervous system was also investigated by means of neurobehavioral evaluations of mice, aiming to analyze the potential of FTL as anxiogenic and antidepressant. Since several pathways can be involved in depression, many evidences have associated depression symptoms with a dysfunction in glutamatergic signaling, especially the hyperactivation of N-methyl-D-aspartate (NMDA) receptors. In this context, antagonists of these receptors have been showed antidepressant action. Studies revealed that after intraperitoneal administration of FTL in mice, this substance produces an attenuation of the neurobehavioral effects mediated by both N-methyl-D-aspartate (NMDA) and L-Arginine /NO /cGMP receptors in vivo and in silico (Sanacora et al. 2011). Furthermore, in other study performed by Jacques (2012), FTL demonstrated neuroprotective activity against glutamatergic neurotoxicity in a model of hippocampal slices of mice treated in vitro with glutamate. In this context, it was verified of FTL could reverse the scenario of depression through the glutamatergic pathway.

Recently, Damasceno et al. (2016) have shown that FTL has antinociceptive activity, indicating a possible interference with the glutamatergic system through its interaction with transient potential receptor 1 (TRPV1), suggesting that the effect of FTL on glutamate induced nociception occurs due to reduction of glutamate release via TRPV1 channel blockade. FTL acts as an antagonist of the TRPV1 channel leading to a reduction in the release of glutamate. In addition, other receptors showed a role for TRPA1 and TRPM8. Abdon et al. (2009) verified the effect of FTL against gastric damage induced by ethanol. It was reported that FTL have protective effects against gastric damage induced by ethanol. In addtition, FTL decreases gastric lesions through its action in stimulating endogenous prostaglandins, nitric oxide, and opening of ATP and $\mathrm{K}^{+}$channels. However, FTL failed to prevent ethanol-induced changes in meaning glutathione (GSH) and malondialdehyde (MDA). Hence, FTL may be a good therapeutic agent for the development of new drugs for the treatment of gastric ulcer. 


\section{Final considerations}

Frutalin has several biological activities such as antinociceptive, antitumor, gastroprotective, cytotoxic and the ability to recognize cancer cells, thus presenting an excellent biotechnological potential, especially in the area of toxicity and diagnosis of cancer cells. However, more studies are required to qualify the clinical use of this lectin.

\section{Bibliography}

ABDON APV, SOUZA GC, SOUZA LNC. Gastroprotective potential of frutalin, $\alpha$-D-galactose binding lectin, against ethanolinduced gastric lesions. Fitoterapia. 2012;83, (3):604-608.

BRANDO-LIMA AC, et al. Involvement of phosphatidylinositol-3 kinase-Akt and nuclear fator kappa-B pathways in the effect of frutalin on human lymphocyte. International Immunopharmacology. 2006;6:465-472.

BRANDO-LIMA AC, SALDANHA-GAMA RF, HENRIQUES MGMO, MONTEIRO-MOREIRA ACO, MOREIRA RA, BARJA-FIDALGO C. Frutalin, a galactose-binding lectin, induces chemotaxis and rearrangement of actin cytoskeleton in human neutrophils: Involvement of tyrosine kinase and phosphoinositide 3-kinase. Toxicology and Applied Pharmacology. 2005;208:145-154.

BROCKHAUSEN I. Pathways of O-glycan biosinthesis in cancer cells. Biochimica et Biophysica Acta - General Subjects. 1999;1473(1):67-95.

CARVALHO JCT. Fitoterápicos Anti-inflamatórios. Ribeirão Preto: Tecmed, 2015;116:125-131.

CAVALCANTE MDES, et al. A panel of glycoproteins as candidate biomarkers for early diagnosis and treatment evaluation of B-cell acute lymphoblastic leukemia. Biomarker Research. 2016:4-1.

CONSTANCIO APN. Utilização da Frutalina, uma lectina a-D-galactose ligante de Artocarpus incisa L., no estudo dos linfomas de Hodgkin forma clássica, em Ceará/CE [dissertação]. Fortaleza: Universidade Federal do Ceará/UFC, 2005.

DAMASCENO MB, et al. Frutalin reduces acute and neuropathic nociceptive behaviours in rodent models of orofacial pain. Chemico-Biological Interactions. 2016;256:9-15.

FERREIRA MVP. Frutalina, lectina $\alpha$-D-galactose ligante de Artocarpus incisa L. Um estudo com câncer de mama [thesis]. Fortaleza: Universidade Federal do Ceará/UFC; 2001.

GALLEGO DEL SOL F, NAGANO C, CAVADA BS, CALVETE JJ. The first crystal structure of a Mimosoideae lectin reveals a novel quaternary arrangement of a widespread domain, J. Mol. Biol. 2005;353:574-583.

HAN C, JIN J, XU S, LIU H, LI N, CAO X. Integrin CD11b negatively regulates TLR-triggered inflammatory responses by activating Syk and promoting degradation of MyD88 and TRIF via Cbl-b. Nat. Immunol. 2010;11:734-742.

HARABAYASHI J, KUNO A, TATENO H. Lectin-based structural glycomics: a pratical approach to complex glycans. Electrophoresis. 2011; 32:1118-1128.

JIANG JF, HAN Y, XING LJ, XU YY, XU ZH, CHONG K. Cloning and expression of a novel cDNA encoding a mannosespecific jacalin-related lectin from. Oryza sativa. Toxicon. 2006;47:133-139.

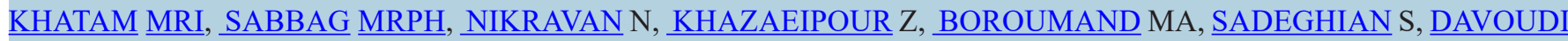
B. The role of neutrophil-gelatinase-associated lipocalin in early diagnosis of contrast nephropathy. Indian J Nephrol. 2015;25:292-296.

KIM HJ, LEE SJ. Antibody-based enzyme-linked lectin assay (ABELLA) for the sialylated recombinant human erythropoietin present in culture supernatant. Journal of Pharmaceutical and Biomedical Analysis. 2008;48(3):716-721. 
LALWANI AK, CAREY TE, GOLDSTEIN IJ, PETERS BP. Lectin binding characteristics of squamous cell carcinomas of the head and neck. Acta Otolaryngol. 1996;116(1):125-131.

MILHOME MVL, FERREIRA FVA, SCHMITT FCL, ROCHA FILHO F D, MOREIRA RA. Frutalin alpha D galactose binding-lectin, antifrutalin rabbitt antibody (FTLrab),galectin3,CK19 and HBME1 as cyto and histological thyroid carcinoma markers. Revista Médica do Paraná. 2004;62-94.

MONTEIRO ACO. Características químicas, físico-químicas e estruturais da frutalina: uma lectina D-galactose ligante de Artocarpus incisa, em Ceará/CE [dissertação]. Fortaleza: Universidade Federal do Ceará/UFC; 1998.

MONTEIRO-MOREIRA AC, PEREIRA HD, VIEIRA NETO AE, MORENO FBMB, LOBO MDP, SOUSA FD, MOREIRA RA. Crystallization and preliminary X-ray diffraction studies of frutalin, an -D-galactose-specific lectin from Artocarpus incisa seeds. Acta Crystallographica. 2015;7:1282-1285.

MOREIRA RA, AINOUZ IL. Isolectins from jackfruit (Artocarpus integrifolia) seeds. Plant. Physiology. 1978:61-118.

NEPOMUCENO DR. Clonagem e expressão de uma lectina de Artocarpus incisa L. (Frutalina) em Escherichia coli, em Ceará/ CE [dissertação]. Fortaleza: Universidade Federal do Ceará/UFC; 2008.

OLIVEIRA C, FELIX W, MOREIRA RA, TEXEIRA JA, DOMINGUES L. Expression of frutalin, an $\alpha$-d-galactose-binding jacalin-related lectin, in the yeast Pichia pastoris protein expression and purification. Protein Expression and Purification. 2008;60:188-193.

OLIVEIRA C, NICOLAU A, TEXEIRA JA, DOMINGUES L. Cytotoxic Effects of Native and Recombinant Frutalin, a Plant Galactose-Binding Lectin, on HeLa Cervical Cancer Cells. Journal of Biomedicine and Biotechnology. 2011:16-10.

OLIVEIRA C, TEIXEIRA JA, SCHMITT F, DOMINGUES L. A comparative study of recombinant and native frutalin binding to human prostate tissues. BMC Biotechnology. 2009:9-78.

OLIVEIRA C, TEXEIRA JA, DOMINGUES L. Recombinant production of plant lectins in microbial systems for biomedical application - the frutalin. Frontiers in Plant Science. 2014;8:5-390.

PEREIRA C, et al. Involvement of AKT and NFkappa-B on lymphocyte activation by frutalin, a galactose-binding lectin. Nitric Oxide, Cytokines and inflammation-An International Symposium. 2004;95:1072-1081.

PEREIRA HM, et al. Crystal Structure of Frutalin from Artocarpus incisa. Protein Data Bank. 2015; 227:292-293.

PEUMANS WJ, VAN DAMME EJM. Lectins as plant defense proteins. Plant Physiology. 1995;109(2):347-352.

SILVA WJ, et al. Effects of essential oils on Aedes aegypti larvae: alternatives to environmentally safe insecticides. Bioresour. Technol., 2008;99:3251-325.

SCHOEPPNER HL, RAZ A, HO SB, BRESALIER RS. Expression of an endogenous galactose-binding lectin correlates with neoplastic progression in the colon. Cancer. 1995;75(12):2818-26.

SHARON N, LIS H. History of lectins: from hemagglutinins to biological recognition molecules. Glycobiology. 2004;14(11):53-62.

YOON KS, LEE KP, KLOCHKOVA TA, KIM GH. Molecular characterization of the lectin, bryohealin, involved in protoplast regeneration of the marine alga Bryopsis plumosa (Chlorophyta). J Phycol. 2008;44:103-112.

VIEIRA NETO AE. Caracterização estrutural da frutalina, uma lectina a-D-galactose ligante de sementes de Artocarpus incisa e análise das suas bases moleculares de ligação a D-glactose, em Ceará/CE [dissertação]. Ceará: Universidade Federal do Ceará/UFC; 2015.

ZHANG DL, LU CH, YU DH, WANG ZY. Characterization and functional analysis of a tandem-repeat galectin-9 in large yellow croaker Larimichthys crocea. Fish and Shellfish Immunology. 2016;26(3):791-810. 


\section{Bianca Régia Silva,}

Biotechnology Nucleus of Sobral, Federal University of Ceara, Sobral, CE, Brazil

e-mail: biancasiva-12@hotmail.com

Participação do autor:

\section{Franscisco Léo Nascimento de Aguiar}

2. Laboratory of Manipulation of Oocytes and Preantral Follicles (LAMOFOPA), State University of Ceará, Fortaleza, Ceará, Brazil e-mail:leo7aguiar@gmail.com

Participação do autor:

\section{José Roberto Viana Silva}

Biotechnology Nucleus of Sobral, Federal University of Ceara, Sobral, CE, Brazil

e-mail:jrvsilva@ufc.br

Participação do autor: 